\title{
Drosophilidae (Insecta, Diptera) in the state of Pará (Brazil)
}

\author{
Rosângela Santa-Brígida ${ }^{1 *}$, Hermes José Schmitz ${ }^{2}$ \& Marlúcia Bonifácio Martins ${ }^{3}$ \\ ${ }^{1}$ Universidade Federal do Paraná, Curitiba, PR, Brazil \\ ${ }^{2}$ Universidade Federal da Integração Latino-Americana, Foz do Iguaçu, PR, Brazil \\ ${ }^{3}$ Museu Paraense Emílio Goeldi, Zoologia, Belém, PA, Brazil \\ *Corresponding author: Rosângela Santa-Brígida, e-mail: rosangela_brigida@yahoo.com.br
}

\begin{abstract}
SANTA-BRÍGIDA, R., SCHMITZ, H.J., MARTINS, M.B. Drosophilidae (Insecta, Diptera) in the state of Pará (Brazil). Biota Neotropica. 17(1): e20160179. http://dx.doi.org/10.1590/1676-0611-BN-2016-0179
\end{abstract}

\begin{abstract}
This list contains information on the Drosophilidae that occur in the Brazilian state of Pará, Amazon biome, and an analysis of the current knowledge of Drosophilidae based on museum material and literature records. This list includes a detailed account of the material deposited in the entomological collections of the Museu Paraense Emílio Goeldi and Museu de Zoologia da Universidade de São Paulo, up to 2015. In total, 122 species of Drosophilidae were registered, including 27 new records for the state of Pará and 22 are new records for the Amazon; for instance, the genera Diathoneura and Rhinoleucophenga, and three new records for Brazil, (Drosophila fasciola, Diathoneura flavolineata and Drosophila neochracea). The state of Pará is the third state in Brazil in terms of numbers of species of Drosophilidae, with $17 \%$ locally native species. Despite the high species richness, there is still a lot to be known about the states's Drosophilidae fauna. This study highlights the importance of scientific collections, particularly as an aid to study regional biodiversity.
\end{abstract}

Keywords: species composition, Amazon, Diathoneura, Rhinoleucophenga.

\section{Drosophilidae (Insecta, Diptera) no estado do Pará (Brasil)}

\begin{abstract}
Resumo: As informações reunidas nesta lista referem-se à ocorrência de Drosophilidae no estado do Pará, bioma Amazônia com uma análise do estado de conhecimento do grupo. Este documento contém uma revisão detalhada do material depositado na Coleção Entomológica do Museu Paraense Emílio Goeldi e Museu de Zoologia da Universidade de São Paulo até 2015, bem como a análise de toda a literatura relevante. Um total de 122 espécies de Drosophilidae foi registrado, com 27 novos registros para o estado do Pará e 22 são novas ocorrências para a Amazônia. Entre estes o primeiro registro para os gêneros Diathoneura e Rhinoleucophenga, além de três registros novos para o Brasil (Drosophila fasciola, Diathoneura flavolineata e Drosophila neochracea). O estado do Pará é o terceiro maior estado brasileiro em termos de número de espécies registradas, com $17 \%$ das espécies com ocorrência exclusiva no Estado. Ainda assim há grandes lacunas para o conhecimento da fauna dos Drosophilidae do estado. Este estudo destaca a importância das coleções científicas, acima de tudo, como um elemento crucial para compreensão da biodiversidade regional.
\end{abstract}

Palavras-chave: Composição de espécies, Amazônia, Diathoneura, Rhinoleucophenga.

\section{Introduction}

There are more than 4,200 Drosophilidae species in the world (Bächli 2015). This number will most likely increase as new species are continuously being described, particularly in the Neotropical region (Silva \& Martins 2004, Vilela \& Bächli 2005, Ratcov \& Vilela 2007, Culik \& Ventura 2009, Schmitz et al. 2009, Figuero \& Rafael 2011, Figuero et al. 2012, Gottschalk et al. 2012, Acurio et al. 2013, Poppe et al. 2014, Junges \& Gottschalk 2014, Guillín \& Rafael 2015, Junges et al. 2016, Vidal \& Vilela 2015). In Brazil, the Drosophilidae family is represented by 16 genera and 305 species (Tidon et al. 2015). Taxonomic inventories are needed to we fill the knowledge gaps on biodiversity (Hortal et al. 2015). Althought the first collections for the Amazon dating from
1920-1959 period (Duda 1927; Hendel 1936; Dobzhansky \& Pavan 1943; Pavan 1950; Pavan 1959), the richness of Drosophilidae fauna of the brazilian Amazon is still little known, states such as Acre, Amapá, Roraima, Rondônia e Tocantins have less than 12 recorded species (Gottschalk et al. 2008). Among the Amazonian states, only Amazonas and Pará have more consistent inventory Drosophilid (Bächli 2015). As the result, the scenario of the distribution of species for this region is still very incomplete.

The Drosophilidae fauna of the state of Pará has been sporadically studied since 1920, by pioneer systematists (Duda 1927; Hendel 1936; Burla et al. 1949), evolutionary biologists (Pavan 1950) and more recently by ecologists (De Toni et al. 2005; Martins \& Oliveira 2007; 
Martins \& Santos 2007; Silva \& Martins 2009; Praxedes \& Martins 2014 and Robe et al. 2014). Currently, in Pará there are 75 Drosophilidae species from nine genera that are from two subfamilies Steganinae and Drosophilinae (Bächli 2015).

Throughout the years a great volume of material has accumulated in scientific collections. Material from the state of Pará is, for the most part, deposited in the collections Museu Paraense Emílio Goeldi (MPEG) and Museu de Zoologia da Universidade de São Paulo (MZUSP). The Drosophilidae species in the MPEG deposit were mostly collected in the Amazon, from expeditions dating back to the 1970s. At MZUSP it is known to hold Brazil's largest Diptera collection, with specimens from large expeditions during the 1940s and 1950s, particularly in the Amazon, coordinated by Dr. Crodowaldo Pavan (Magalhães 2010). We analyzed material from these two collections and using literature data to complement our survey. Our goal was to list the species of Drosophilidae that are found in the state of Pará, with the aim to fill a knowledge gap of Drosophilae found in the Amazon.

\section{Material and Methods}

The state of Pará, Northern Brazil, has an area of 1,248,000 km², is completely immersed in the Amazon Biome (IBGE 2010). The climate is Equatorial (Am) and Tropical (As), according to Köppen classification, with a mean temperature of $25^{\circ} \mathrm{C}$ and minimum precipitation of $1,300 \mathrm{~mm}$ per year and maximum of 2,400 $\mathrm{mm}$ per year (Moraes et al. 2005).
Occurrence data for Drosophilidae was compiled based on literature research, and the examination of material deposited in the entomological collection of the MPEG and MZUSP up to 2015. Data was plotted on a map of Brazil's municipalities. The identification of all Drosophilidae at MPEG was rechecked. For this, we dissected the genitalia of, and examined, up to five males of each species (following the procedure described by Bächli et al. 2004). The identity of species represented only by females was checked using external morphological characters whenever possible. Drosophilidae specimens that were in $70 \%$ ethanol and from the wet collection at MPEG, were mounted on entomological pins after being dissected. The specimen terminalia were stored in microtubes containing glycerin and pinned together with the specimen. Specimens deposited in the MZUSP had already been dissected and their terminalia were stored in microtubes containing glycerin, thus facilitating confirmation. The individual number of each species deposited in the MPEG collection was recorded. The total number of individual specimens of each species found in MZUSP was not accounted.

We searched Drosophilidae literature using the website compiled by Gerhard Bächli (Bächli 2015). We also verified and analyzed each literature reference for the state of Pará.

\section{Results and Discussion}

In total, 122 species of Drosophilidae in 11 genera were found, distributed in 24 of the 144 municipalities of the state of Pará (Figure 1). Nine genera belong to the subfamily Drosophilidae (Chymomyza Czerny,

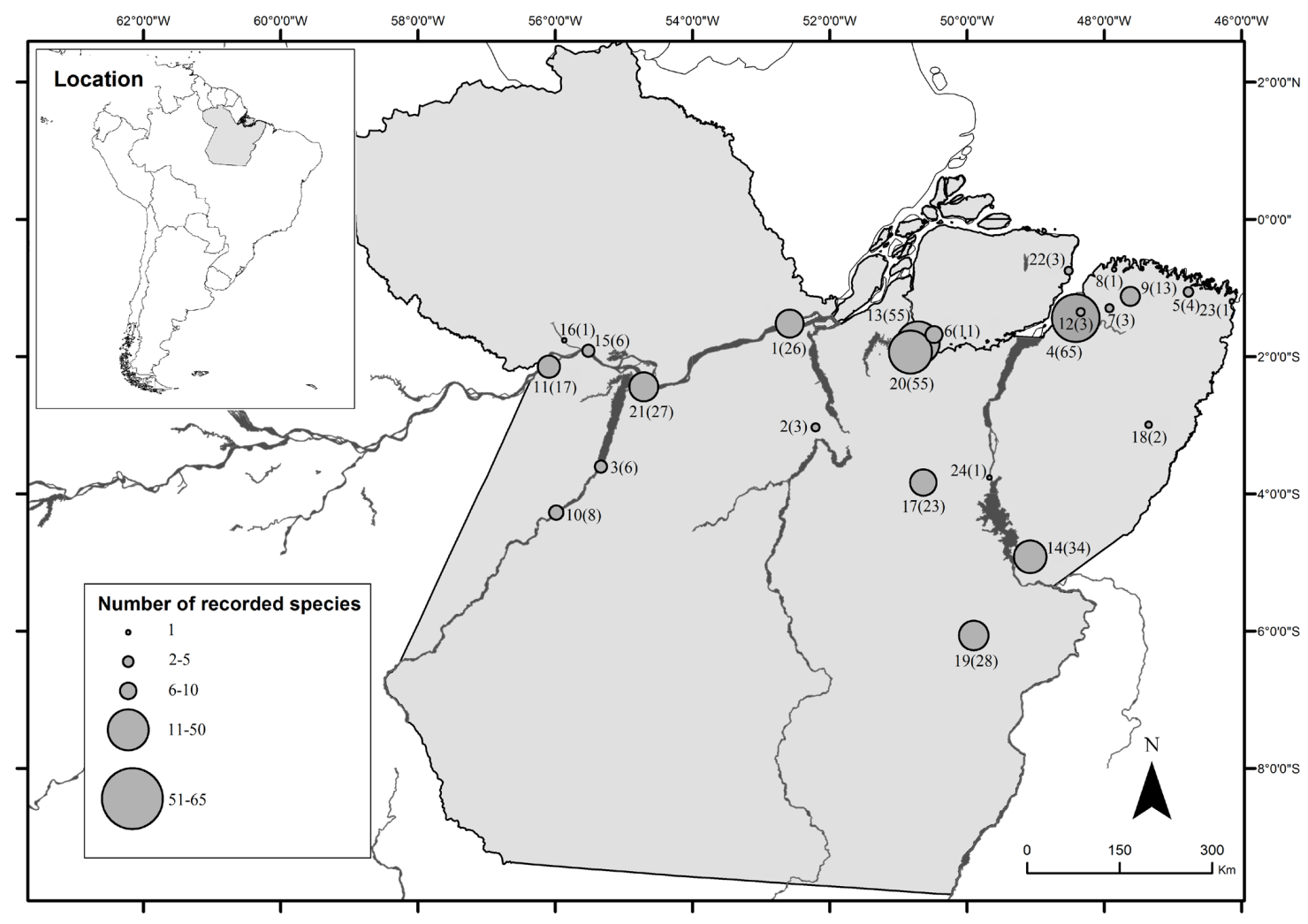

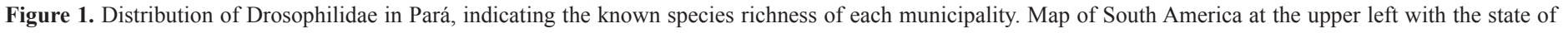

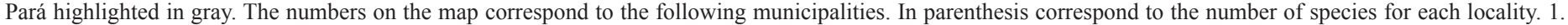

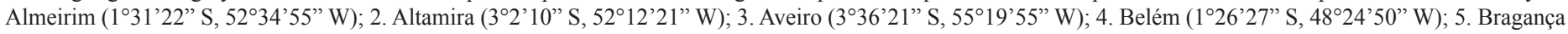

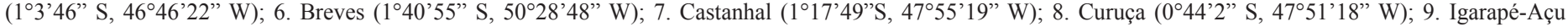

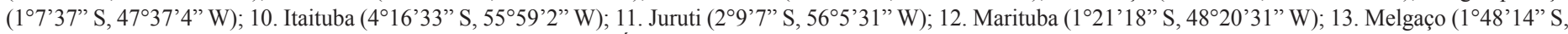

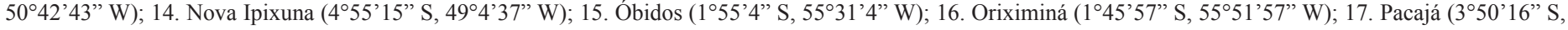

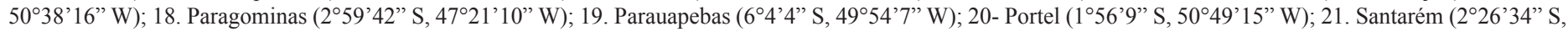

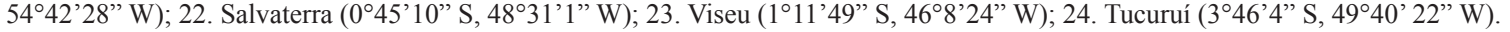


1903, Diathoneura Duda, 1924, Drosophila Fallén, 1823, Hirtodrosophila Duda, 1923, Mycodrosophila Oldenberg, 1914, Neotanygastrella Duda, 1925, Scaptodrosophila Duda, 1923, Zaprionus Coquillett, 1901 and Zygothrica Wiedemann, 1830) and two belong to Steganinae (Leucophenga Mik, 1886 and Rhinoleucophenga Hendel, 1917). The actualized list of all species can be found in Table 1. References in the column 'record' of Table 1 represent the oldest record for the species. The table also shows the municipalities of Pará where each species was recorded from, and the total number of specimens deposited in the collection of the Museu Paraense Emílio Goeldi. The map (Figure 1) shows the distribution of Drosophilidae in Pará, indicating the known species richness of each municipality. The municipality of Belém had the greatest number of species, 65, followed by Melgaço (MEL) and Portel (POR), with 55 species, and Santarém (SAN), with 27. More than half of the species (66) occurred in less than three municipalities. Drosophila malerkotliana, an invasive species present in the Amazon since the 1980s, was the most widespread species, occurring in 15 municipalities. The second most abundant species was the native species Drosophila nebulosa, Drosophila sturtevanti and Drosophila willistoni, which were found in 13 of the 24 municipalities.

Table 1. Drosophilidae recorded in the state of Pará, Brazil. Municipalities: $\mathrm{ALM}=\mathrm{Almeirim}, \mathrm{ALT}=\mathrm{Altamira}, \mathrm{AVE}=\mathrm{Aveiro}, \mathrm{BEL}=\mathrm{Belém}, \mathrm{BRA}=\mathrm{Bragança}, \mathrm{BRE}=\mathrm{Breves}$, $\mathrm{CAS}=$ Castanhal, $\mathrm{CUR}=$ Curuça, $\mathrm{IGA}=$ Igarapé-Açu, ITA = Itaituba, JUR $=$ Juruti, MAR $=$ Marituba, MEL $=$ Melgaço, NIP $=$ Nova Ipixuna, OBI $=$ Óbidos, ORI $=$ Oriximiná, $\mathrm{PAC}=$ Pacajá, $\mathrm{PARG}=$ Paragominas, $\mathrm{PARP}=$ Parauapebas, $\mathrm{POR}=$ Portel, $\mathrm{SAN}=$ Santarém, $\mathrm{SAL}=$ Salvaterra, TUC= Tucuruí and VIS= Viseu. Records: $\mathrm{MPEG}=\mathrm{Museu}$ Paraense Emílio Goeldi and MZUSP= Museu de Zoologia da Universidade de São Paulo collections. \# in col: Total Drosophilidae specimens deposited in the MPEG.

\begin{tabular}{|c|c|c|c|}
\hline Species & Municipalities & Records & \# in col \\
\hline \multicolumn{4}{|l|}{ Subfamily Drosophilinae } \\
\hline \multicolumn{4}{|l|}{ Genus Chymomyza } \\
\hline \multicolumn{4}{|l|}{ aldrichii group } \\
\hline${ }^{3}$ Chymomyza bicoloripes (Malloch, 1926) & ALM and SAN & Hendel (1936) & \\
\hline Chymomyza diatropa Grimaldi, 1986 & MEL and POR & MPEG and Schmitz et al. (2013) & 23 \\
\hline \multicolumn{4}{|l|}{ Genus Diathoneura } \\
\hline 1,2,4 Diathoneura flavolineata Duda, 1927 & BEL & MZUSP & \\
\hline \multicolumn{4}{|l|}{ Genus Drosophila } \\
\hline \multicolumn{4}{|l|}{ Subgenus Drosophila } \\
\hline \multicolumn{4}{|l|}{ annulimana group } \\
\hline${ }^{I}$ Drosophila annulimana Duda, 1927 & BEL, MEL and POR & MPEG & 5 \\
\hline Drosophila araicas Pavan \& Nacrur, 1950 & ALM, BEL,MEL and POR & MPEG and Val (1982) & 7 \\
\hline $\begin{array}{l}1,4 \text { Drosophila arapuan Da Cunha \& Pavan, in Pavan \& Da } \\
\text { Cunha, } 1947\end{array}$ & PARP & MPEG & 1 \\
\hline Drosophila ararama Pavan \& Da Cunha, 1947 & BEL and NIP & MPEG, Pavan \& Cunha (1947) & 14 \\
\hline${ }^{3}$ Drosophila caxiuana Gottshalk et al., 2012 & MEL and POR & MPEG and Gottschalk et al. (2012) & 5 \\
\hline \multicolumn{4}{|l|}{ bromeliae group } \\
\hline${ }^{3}$ Drosophila speciosa Silva \& Martins, 2004 & BEL,CUR, MEL and POR & MPEG and Silva \& Martins (2004) & 429 \\
\hline \multicolumn{4}{|l|}{ calloptera group } \\
\hline Drosophila atrata Burla \& Pavan, 1953 & AVE and PARP & MPEG and Burla \& Pavan (1953) & 2 \\
\hline Drosophila calloptera Schiner, 1868 & BEL, MEL, POR and SAN & MPEG and Burla \& Pavan (1953) & 5 \\
\hline${ }^{1,4}$ Drosophila quadrum (Wiedemann, 1830 ) & OBI & MZUSP & \\
\hline \multicolumn{4}{|l|}{ canalinea group } \\
\hline${ }^{3}$ Drosophila annularis Sturtevant, 1916 & SAN & Hendel (1936) & \\
\hline 1,4 Drosophila annulosa Duda, 1929 & MEL and POR & MPEG & 2 \\
\hline Drosophila canalinea Patterson \& Mainland, 1944 & BEL, MEL, PARP and POR & MPEG and Patterson \& Stone (1952) & 1 \\
\hline Drosophila davidgrimaldii Vilela \& Bächli, 1990 & MEL, SAN and POR & MPEG and Vilela \& Bächli (1990) & 1 \\
\hline${ }^{3}$ Drosophila hendeli Vilela \& Bächli, 1990 & SAN & Vilela \& Bächli (1990) & \\
\hline \multicolumn{4}{|l|}{ caponei group } \\
\hline${ }^{1,4}$ Drosophila caponei Pavan \& Cunha, 1947 & BEL & MPEG & 9 \\
\hline 1,2,4 Drosophila neochracea Wheeler, 1959 & BEL and TUC & MPEG & 5 \\
\hline \multicolumn{4}{|l|}{ cardini group } \\
\hline \multicolumn{4}{|l|}{ cardini subgroup } \\
\hline Drosophila cardini Sturtevant, 1916 & BEL, NIP, PAC and PARP & MPEG and Heed \& Russell (1971) & 17 \\
\hline Drosophila cardinoides Dobzhansky \& Pavan, 1943 & AVE, BEL, IGA, MAR, NIP and PARP & MPEG and Streisinger (1946) & 9 \\
\hline Drosophila neocardini Streisinger, 1946 & MEL, NIP, PAC and POR & MPEG and Silva \& Martins (2009) & 2 \\
\hline Drosophila neomorpha Heed \& Wheeler, 1957 & $\begin{array}{l}\text { ALM, BEL, JUR, MEL, NIP, PAC, PARP } \\
\text { and POR }\end{array}$ & MPEG and De Toni et al. (2005) & 11 \\
\hline Drosophila parthenogenetica Stalker, 1953 & MEL, NIP, PAC and POR & MPEG and De Toni et al. (2005) & 6 \\
\hline Drosophila polymorpha Dobzhansky \& Pavan, 1943 & $\mathrm{BEL}$ and BRE & Dobzhansky \& Da Cunha (1955) & \\
\hline \multicolumn{4}{|l|}{ coffeata group } \\
\hline Drosophila coffeata Williston, 1896 & ALM, BEL, MEL, PARP, POR and SAN & MPEG and Hendel (1936) & 91 \\
\hline Drosophila fuscolineata Duda, 1925 & BEL & MPEG and Dobzhansky \& Pavan (1950) & 2 \\
\hline
\end{tabular}

${ }^{1}$ New records for the state of Pará; ${ }^{2}$ New records for Brazil; ${ }^{3}$ Species that are recorded in Brazil only in the state of Pará; ${ }^{4}$ New records for Amazon 
Santa-Brígida, R. et al.

Table 1. Continued..

\begin{tabular}{|c|c|c|c|}
\hline Species & Municipalities & Records & \# in col \\
\hline \multicolumn{4}{|l|}{ dreyfusi group } \\
\hline Drosophila camargoi Dobzhansky \& Pavan in Pavan, 1950 & BEL BRE, MEL, NIP and POR & MPEG and Pavan (1959) & 71 \\
\hline${ }^{3}$ Drosophila decemseriata Hendel, 1936 & SAN & Hendel (1936) & \\
\hline \multicolumn{4}{|l|}{ flavopilosa group } \\
\hline${ }^{3}$ Drosophila melina Wheeler, 1962 & BEL & MPEG and Santos \& Martins 2000 & 256 \\
\hline \multicolumn{4}{|l|}{ guarani group } \\
\hline \multicolumn{4}{|l|}{ guaramunu subgroup } \\
\hline${ }^{1,4}$ Drosophila griseolineata Duda, 1927 & PARP & MPEG & 1 \\
\hline \multicolumn{4}{|l|}{ guarani subgroup } \\
\hline Drosophila ornatifrons Duda, 1927 & BEL & MPEG and Pavan (1959) & 1 \\
\hline \multicolumn{4}{|l|}{ pallidipennis subgroup } \\
\hline Drosophila pallidipennis Dobzhansky \& Pavan, 1943 & BEL & Dobzhansky \& Pavan (1950) & \\
\hline \multicolumn{4}{|l|}{ peruensis subgroup } \\
\hline Drosophila peruviana Duda, 1927 & AVE and BEL & MZSP and Pavan (1959) & \\
\hline \multicolumn{4}{|l|}{ repleta group } \\
\hline \multicolumn{4}{|l|}{ fasciola subgroup } \\
\hline Drosophila ellisoni Vilela, 1983 & ALM, BEL, IGA, JUR, NIP and PAC & MPEG and Vilela (1983) & 11 \\
\hline 1,2,3,4 Drosophila fasciola Williston, 1896 & NIP, PAC and PARP & MPEG & 7 \\
\hline Drosophila fascioloides Dobzansky \& Pavan, 1943 & BEL & Wasserman (1962) & \\
\hline${ }^{1,4}$ Drosophila ivai Vilela, 1983 & ALM, NIP, PAC, PARP and POR & MPEG & 19 \\
\hline${ }^{1,4}$ Drosophila mapiriensis Vilela \& Bächli, 1990 & BEL, MEL, NIP and POR & MPEG & 6 \\
\hline Drosophila moju Pavan, 1950 & BEL, JUR, NIP and PARP & MEPG and Vilela (1983) & 11 \\
\hline 32Drosophila mojuoides Wasserman, 1962 & BEL & MPEG and Vilela (1983) & 1 \\
\hline${ }^{1,4}$ Drosophila papei Bächli \& Vilela, 2002 & NIP and PARP & MPEG & 12 \\
\hline${ }^{1,4}$ Drosophila querubimae Vilela, 1983 & MEL, NIP, PAC and POR & MPEG & 3 \\
\hline \multicolumn{4}{|l|}{ hydei subgroup } \\
\hline Drosophila hydei Sturtevant, 1921 & BEL & MPEG and Martins \& Oliveira (2007) & 6 \\
\hline \multicolumn{4}{|l|}{ mercatorum subgroup } \\
\hline 'Drosophila mercatorum Patterson \& Wheeler, 1942 & $\mathrm{BEL}$ & MPEG & 1 \\
\hline${ }^{1}$ Drosophila paranaensis Barros, 1950 & NIP and PARP & MPEG & 7 \\
\hline \multicolumn{4}{|l|}{ mulleri group } \\
\hline${ }^{I}$ Drosophila aldrichi Patterson, in Patterson \& Crow, 1940 & ALT, MEL and POR & MPEG & 10 \\
\hline \multicolumn{4}{|l|}{ repleta subgroup } \\
\hline Drosophila eleonorae Tosi et al., 1990 & ALT & MPEG and Tosi et al. (1990) & 41 \\
\hline Drosophila fulvimacula Patterson \& Mainland, 1944 & $\begin{array}{l}\text { ALM, BEL, JUR, MEL, NIP, PAC, PARP, } \\
\text { POR }\end{array}$ & $\begin{array}{l}\text { MPEG and Dobzhansky \& Da Cunha } \\
(1955)\end{array}$ & 52 \\
\hline $\begin{array}{l}{ }^{1,4} \text { Drosophila limensis Pavan \& Patterson in Pavan \& Da } \\
\text { Cunha, } 1947\end{array}$ & MEL and POR & MPEG & 2 \\
\hline${ }^{1}$ Drosophila repleta Wollaston, 1858 & MEL and POR & MPEG & 11 \\
\hline \multicolumn{4}{|l|}{ tripunctata group } \\
\hline \multicolumn{4}{|l|}{ I subgroup } \\
\hline Drosophila mediocris Frota-Pessoa, 1954 & MEL and POR & MPEG and Praxedes \& Martins (2014) & 1 \\
\hline Drosophila neoguaramunu Frydenberg, 1956 & $\mathrm{BEL}$ & MPEG and Martins \& Santos (2007) & 1 \\
\hline${ }^{1,4}$ Drosophila setula Heed \& Wheeler, 1957 & PAC & MPEG & 3 \\
\hline \multicolumn{4}{|l|}{ II subgroup } \\
\hline${ }^{1,4}$ Drosophila cuaso Bächli, Vilela \& Ratcov, 2000 & ALM, BEL, MEL, NIP, PARP and POR & MPEG & 9 \\
\hline \multicolumn{4}{|l|}{ III subgroup } \\
\hline Drosophila addisoni Pavan, 1950 & BEL & Pavan (1959) & \\
\hline Drosophila frotapessoai Vilela \& Bächli, 1990 & BEL, MEL and POR & MPEG and Martins \& Oliveira (2007) & 1 \\
\hline Drosophila medioimpressa Frota-Pessoa, 1954 & MEL and POR & MPEG and Praxedes \& Martins (2014) & 1 \\
\hline Drosophila mediopicta Frota-Pessoa, 1954 & MEL and POR & MPEG and Praxedes \& Martins (2014) & 1 \\
\hline Drosophila mediostriata Duda, 1925 & BEL, MEL and POR & Martins \& Oliveira (2007) & \\
\hline Drosophila mesostigma Frota-Pessoa, 1954 & $\mathrm{BEL}$ & Val (1982) & \\
\hline${ }^{1,4}$ Drosophila paramediostriata Townsend \& Wheeler, 1955 & BEL and PARP & MPEG & 4 \\
\hline${ }^{1,4}$ Drosophila trapeza Heed \& Wheeler, 1957 & PARP & MPEG & 1 \\
\hline \multicolumn{4}{|l|}{ IV subgroup } \\
\hline${ }^{1,4}$ Drosophila albicans Frota-Pessoa, 1954 & PARP & MPEG & 4 \\
\hline
\end{tabular}

\footnotetext{
${ }^{1}$ New records for the state of Pará; ${ }^{2}$ New records for Brazil; ${ }^{3}$ Species that are recorded in Brazil only in the state of Pará; ${ }^{4}$ New records for Amazon
} 
Table 1. Continued...

\begin{tabular}{|c|c|c|c|}
\hline Species & Municipalities & Records & \# in col \\
\hline \multicolumn{4}{|l|}{ Without subgroup } \\
\hline${ }^{3}$ Drosophila argenteifrons Wheeler, 1954 & CAS & Wheeler (1954) & \\
\hline \multicolumn{4}{|l|}{ Subgenus Phloridosa } \\
\hline${ }^{1,4}$ Drosophila lutzii Sturtevanti, 1916 & BEL & MPEG & 6 \\
\hline \multicolumn{4}{|l|}{ Subgenus Sophophora } \\
\hline \multicolumn{4}{|l|}{ melanogaster group } \\
\hline \multicolumn{4}{|l|}{ ananassae subgroup } \\
\hline Drosophila ananassae Doleschall, 1858 & $\begin{array}{l}\text { BEL, BRA, IGA, MEL, NIP, PAC, PRAP } \\
\text { and POR }\end{array}$ & MPEG and Praxedes \& Martins (2014) & 107 \\
\hline Drosophila malerkotliana Parshad \& Paika, 1964 & $\begin{array}{l}\text { ALM, BEL, BRA, BRE, IGA, JUR, MEL, } \\
\text { NIP, PAC, PARG, PARP, POR, SAN, SAL } \\
\text { and VIS }\end{array}$ & MPEG and Martins (2001) & 533 \\
\hline \multicolumn{4}{|l|}{ melanogaster subgroup } \\
\hline Drosophila melanogaster Meigen, 1830 & BEL, MEL and POR & MPEG and David et al. (2006) & 15 \\
\hline Drosophila simulans Sturtevant, 1919 & ALM, BEL, IGA, JUR, MEL, NIP and POR & MPEG and Dobzhansky \& Pavan (1950) & 44 \\
\hline \multicolumn{4}{|l|}{ montium subgroup } \\
\hline Drosophila kikkawai Burla, 1954 & BEL, IGA, MEL, NIP, PAC, PARP and POR & MPEG and Praxedes \& Martins (2014) & 88 \\
\hline \multicolumn{4}{|l|}{ saltans group } \\
\hline \multicolumn{4}{|l|}{ cordata subgroup } \\
\hline Drosophila neocordata Magalhães, 1956 & ALM, BEL, MEL, NIP and POR & MPEG and Praxedes \& Martins (2014) & 9 \\
\hline \multicolumn{4}{|l|}{ elliptica subgrupo } \\
\hline $\begin{array}{l}\text { Drososphila neoelliptica Pavan \& Magalhães in Pavan, } \\
1950\end{array}$ & & MPEG and Praxedes \& Martins (2014) & 1 \\
\hline \multicolumn{4}{|l|}{ parasaltans subgroup } \\
\hline Drosophila parasaltans Magalhães, 1956 & ALM, JUT, MEL and POR & MPEG and Praxedes \& Martins (2014) & 2 \\
\hline Drosophila subsaltans Magalhães, 1956 & ALM, BEL, JUR, MEL, NIP, PAC and POR & MPEG and Magalhães (1956) & 2 \\
\hline \multicolumn{4}{|l|}{ saltans subgroup } \\
\hline Drosophila austrosaltans Spassky, 1957 & BEL, JUR, MEL and POR & MPEG and Praxedes \& Martins (2014) & 2 \\
\hline Drosophila prosaltans Duda, 1927 & $\begin{array}{l}\text { ALM, ALT, AVE, BEL, BRA, BRE, JUR, } \\
\text { MEL, NIP, PAC, PARP and POR }\end{array}$ & $\begin{array}{l}\text { MPEG and Dobzhansky \& Streisinger } \\
\text { (1944) }\end{array}$ & 3 \\
\hline Drosophila pseudosaltans Magalhães, 1956 & MEL and POR & MPEG and Bicudo (1973) & 16 \\
\hline Drosophila saltans Sturtevant, 1916 & ALM, MEL and POR & MPEG and De Toni et al. (2005) & 1 \\
\hline \multicolumn{4}{|l|}{ sturtevanti subgroup } \\
\hline Drosophila dacunhai Mourão \& Bicudo, 1967 & MEL and POR & MPEG and Martins et at. (2008) & 5 \\
\hline${ }^{3}$ Drosophila milleri Magalhães, 1962 & MEL and POR & MPEG and Praxedes \& Martins (2014) & 5 \\
\hline Drosophila magalhaesi Mourão \& Bicudo, 1967 & ALM, BEL, JUR, MEL and POR & MPEG and Martins et at. (2008) & 18 \\
\hline Drosophila sturtevanti Duda, 1927 & $\begin{array}{l}\text { ALM, AVE, BEL, BRE, IGA, ITA, JUR, } \\
\text { MEL, NIP, PAC, PARP, POR and SAN }\end{array}$ & MEPG and Dobzhansky (1944) & 132 \\
\hline \multicolumn{4}{|l|}{ willistoni group } \\
\hline \multicolumn{4}{|l|}{ bocainensis subgroup } \\
\hline Drosophila capricorni Dobzhansky \& Pavan, 1943 & BEL, MEL and POR & MPEG and Dobzhansky \& Pavan (1950) & 1 \\
\hline Drosophila fumipennis Duda, 1925 & BEL, BRE, JUR, MEL and POR & MPEG and Pavan (1959) & 35 \\
\hline Drosophila nebulosa Sturtevant, 1916 & $\begin{array}{l}\text { ALM, AVE, BEL, BRE, IGA, JUR, MEL, } \\
\text { NIP, PAC, PARG, PARP, POR and SAL }\end{array}$ & MEPG and Dobzhansky \& Pavan (1950) & 63 \\
\hline \multicolumn{4}{|l|}{ willistoni subgroup } \\
\hline Drosophila equinoxialis Dobzhansky, 1946 & $\begin{array}{l}\text { ALM, BEL, BRE, IGA, MEL, NIP, PAC, } \\
\text { PARP, POR and SAN }\end{array}$ & MPEG and Burla et al. (1949) & 23 \\
\hline $\begin{array}{l}\text { Drosophila paulistorum Dobzhansky \& Pavan in } \\
\text { Burla et al., } 1949\end{array}$ & $\begin{array}{l}\text { ALM, BEL, BRE, IGA, JUR, MEL, NIP, } \\
\text { PAC, PRAP, POR and SAN }\end{array}$ & MPEG and Townsend (1954) & 105 \\
\hline Drosophila tropicalis Burla et a1., 1949 & BEL, MEL, POR, SAN and SAL & MPEG and Burla et al. (1949) & 26 \\
\hline Drosophila willistoni Sturtevant, 1916 & $\begin{array}{l}\text { ALM, BEL, BRA, BRE, IGA, ITA, JUR, } \\
\text { MEL, NIP, PAC, PARP, POR and SAN }\end{array}$ & MPEG and Dobzhansky \& Mayr (1944) & 104 \\
\hline \multicolumn{4}{|l|}{ Ungrouped species } \\
\hline Drosophila impudica Duda, 1927 & BEL, JUR, NIP, PAC and PARP & MPEG, MZSP and Pavan (1959) & 8 \\
\hline Drosophila tuchaua Pavan, 1950 & BEL, MEL and POR & MPEG and Pavan (1950) & 55 \\
\hline \multicolumn{4}{|l|}{ Subgenus Siphlodora } \\
\hline${ }^{1,4}$ Drosophila flexa Loew, 1866 & NIP & MPEG & 2 \\
\hline
\end{tabular}

\footnotetext{
${ }^{1} \mathrm{New}$ records for the state of Pará; ${ }^{2} \mathrm{New}$ records for Brazil; ${ }^{3}$ Species that are recorded in Brazil only in the state of Pará; ${ }^{4}$ New records for Amazon
} 
Santa-Brígida, R. et al.

Table 1. Continued..

\begin{tabular}{|c|c|c|c|}
\hline Species & Municipalities & Records & \# in col \\
\hline \multicolumn{4}{|l|}{ Hirtodrosophila } \\
\hline \multicolumn{4}{|l|}{ Ungrouped species } \\
\hline${ }^{3}$ Hirtodrosophila pictiventris Duda, 1925 & Localities not mentioned & Vilela \& Bächli (2004) & \\
\hline Hirtodrosophila subflavohalterata Burla, 1956 & MEL and POR & Robe et al. 2014 & \\
\hline \multicolumn{4}{|l|}{ Genus Mycodrosophila } \\
\hline${ }^{3}$ Mycodrosophila brunnescens Wheeler \& Takada, 1963 & BEL & Wheeler \&Takada (1963) & \\
\hline${ }^{3}$ Mycodrosophila elegans Wheeler \& Takada, 1963 & CAS & Wheeler \&Takada (1963) & \\
\hline Mycodrosphila projetans Wheeler \& Takada, 1963 & MEL and POR & Robe et al.(2014) & \\
\hline \multicolumn{4}{|l|}{ Genus Neotanygastrella } \\
\hline${ }^{3}$ Neotanygastrella chymomyzoides Duda, 1927 & BEL & Hendel (1936) & \\
\hline Neotanygastrella tricoloripes Duda, 1925 & SAN & Hendel (1936) & \\
\hline \multicolumn{4}{|l|}{ Genus Paraliodrosophila } \\
\hline Paraliodrosophila antennata Wheeler, 1957 & & Wheeler (1954) & \\
\hline \multicolumn{4}{|l|}{ latifasciaeformis group } \\
\hline Scaptodrosophila latifasciaeformis (Duda, 1940) & $\begin{array}{l}\text { BEL, BRE, IGA, JUR, MEL, NIP, PAC, } \\
\text { PARP and POR }\end{array}$ & MPEG and Pavan (1959) & 50 \\
\hline \multicolumn{4}{|l|}{ Genus Zaprionus } \\
\hline \multicolumn{4}{|l|}{ vittiger group } \\
\hline Zaprionus indianus Gupta, 1970 & $\begin{array}{l}\text { ALM, BEL, MEL, NIP, PAC, PARP, POR } \\
\text { and SAN }\end{array}$ & MEPG and David et al. (2006) & 8 \\
\hline \multicolumn{4}{|l|}{ Genus Zygothrica } \\
\hline \multicolumn{4}{|l|}{ dispar group } \\
\hline \multicolumn{4}{|l|}{ aldrichii subgroup } \\
\hline${ }^{3}$ Zygothrica aldrichi Sturtevant, 1920 & BEL & Hendel (1936) & \\
\hline${ }^{3}$ Zygothrica mediovitta Grimaldi, 1987 & SAN & Grimaldi (1987) & \\
\hline Zygothrica microeristes Grimaldi, 1987 & ALM, BEL, ITA, OBI and ORI & MZSP and Grimaldi (1987) & \\
\hline Zygothrica paraldrichi Burla, 1956 & ALM, BEL, ITA, MAR, OBI and SAN & MZSP and Grimaldi (1987) & \\
\hline Zygothrica pilipes Hendel, 1936 & ITA, OBI and SAN & MZSP and Hendel (1936) & \\
\hline${ }^{3} Z$ ygothrica radialis Grimaldi, 1987 & ALM, BEL and ITA & MZSP and Grimaldi (1987) & \\
\hline${ }^{3}$ Zygothrica somatia Grimaldi, 1987 & ALM, OBI and SAN & MZSP and Grimaldi (1987) & \\
\hline Zygothrica zygia Grimaldi, 1987 & OBI and SAN & Grimaldi (1987) & \\
\hline \multicolumn{4}{|l|}{ caudata subgroup } \\
\hline Zygothrica caudata (Hendel, 1913) & SAN & Hendel (1936) & \\
\hline \multicolumn{4}{|l|}{ dispar subgroup } \\
\hline Zygothrica dispar (Wiedmann, 1830) & SAN & MZUSP and Hendel (1936) & \\
\hline Zygothrica prodispar Duda, 1925 & BEL, ITA, MAR and SAN & MPEG and Grimaldi (1987) & 3 \\
\hline \multicolumn{4}{|l|}{ atriangula group } \\
\hline Zygothrica atriangula Duda, 1927 & SAN & Burla (1956) & \\
\hline \multicolumn{4}{|l|}{ atriangulata group } \\
\hline Zygothrica virgatinigra Burla, 1956 & MEL and POR & Robe et al. (2014) & \\
\hline \multicolumn{4}{|l|}{ bilineata group } \\
\hline Zygothrica bilineata (Williston, 1896) & ITA & Grimaldi (1990) & \\
\hline \multicolumn{4}{|l|}{ orbitalis group } \\
\hline Zygothrica orbitalis (Sturtevant, 1916) & SAN & Hendel (1936) & \\
\hline \multicolumn{4}{|l|}{ vittinubila group } \\
\hline${ }^{1,4}$ Zygothrica vittinubila Burla, 1956 & NIP & MPEG and MZUSP & 1 \\
\hline \multicolumn{4}{|l|}{ Ungrouped species } \\
\hline${ }^{3}$ Zygothrica laevifrons Duda, 1927 & SAN & Hendel (1936) & \\
\hline \multicolumn{4}{|l|}{ Subfamily Steganinae } \\
\hline \multicolumn{4}{|l|}{ Genus Leucophenga } \\
\hline${ }^{3}$ Leucophenga argenteofasciata Kahl, 1917 & SAN & Duda (1927) & \\
\hline Genus Rhinoleucophenga & & & \\
\hline${ }^{1,4}$ Rhinoleucophenga punctulata Duda, 1929 & CAS & MPEG & 5 \\
\hline
\end{tabular}

${ }^{1} \mathrm{New}$ records for the state of Pará; ${ }^{2} \mathrm{New}$ records for Brazil; ${ }^{3}$ Species that are recorded in Brazil only in the state of Pará; ${ }^{4} \mathrm{New}$ records for Amazon 
The scientific collections contributed 27 new records for Pará and 22 for the Amazon. Of these, 24 were in the MPEG collection, two in the MZUSP collection and one recorded in both collections. Among the new records, Drosophila fasciola (Williston, 1896), Diathoneura flavolineata Duda, 1927 and Drosophila neochracea Wheeler, 1959 are new records for Brazil. D. fasciola Williston, 1896 had been recorded from the United States, Mexico, El Salvador, Caribbean, Panama, Colombia and Guyana; Drosophila flavolineata (Duda, 1927) only from Costa Rica; and Drosophila neochracea (Wheeler, 1959) from Bolivia and Ecuador (Bächli 2015). The vittimaculosa group of Zygothrica (Z. vittinubila Burla, 1956), the subgenus Siphlodora of Drosophila (D. flexa), the genera Rhinoleucophenga (R. punctulata) and Diathoneura (D. flavolineata) are new records for Pará. Seven cosmopolitan or semi-cosmopolitan species were found in the state; Drosophila ananassae, D. kikkawai, Drosophila malerkotliana Parshad \& Paika, 1964, Drosophila melanogaster Meigen, 1830, D. simulans Sturtevant, 1919, Scaptodrosophila latifasciaeformis (Duda, 1940) and Zaprionus indianus Gupta, 1970.

Of the 29 species listed in Table 1 and which were found in neither collections, only 23 of the species are only known from their original descriptions. Three were recently collected in Pará, but the reference specimens were not preserved (Drosophila pallidipennis Dobzhansky \& Pavan, 1943, Zygothrica aldrichi Sturtevant, 1920 and Zygothrica dispar Wiedemann, 1830). Three species, Drosophila polymorpha Dobzhansky \& Pavan, 1943, Drosophila mesostigma Frota-Pessoa, 1954 and Drosophila mediostriata Duda, 1925 were listed as being in the MPEG collection, but upon re-examination of the respective material, their identification was not confirmed. In the case of $D$. polymorpha, the males were identified as Drosophila neomorpha Heed \& Wheeler, 1957. The similarity between their terminalia and the possibility of introgression between these two species was discussed by De Toni et al. (2005). Upon re-examination of material identified as D. mediostriata, we found Drosophila paramediostriata Townsend \& Wheeler, 1955 and Drosophila frotapessoai Vilela \& Bächli, in addition to underscribed species.

The species Drosophila mediocris Frota-Pessoa, 1954, Drosophila medioimpressa Frota-Pessoa, 1954, Drosophila neoelliptica Pavan \& Magalhães, 1950, Drosophila pseudosaltans Magalhães, 1956 and D. milleri Magalhães, 1962, mentioned in the literature, are represented in the MPEG collection. However, only by females preserved in ethanol, precluding detailed examination of the parts that are necessary to confirm identification. Among these, only D. milleri was not known from other parts of Brazil, being historically restricted to Puerto Rico.

Wheller (1957), suggests that the presence of Hirtodrosophila thoracis (Williston, 1896) in Pará, based on Burla (1956). However, here, we considered this record as belonging to Paraliodrosophila antennata Wheeler, 1957, following Vilela \& Bächli (2007), according to whom the genitalia of the holotype of $P$. antennata was illustrated by Burla as if it was H. thoracis.

Among the species recorded from Pará, 21 species have been nowhere else in Brazil, but have been recorded or observed in other countries (Table 1). Most of those species had only been previously found in Northern localities of the Neotropical region, particularly Colombia, Central America and Caribbean (Bächli 2015). This finding suggests an affinity between the Amazon fauna and the fauna of those other regions.

Additionally, six species occur only in Pará: D. caxiuana, D. speciosa, $Z$. somatia, D. hendeli, D. decemseriata and M. brunnescens. The last three are known only from their original descriptions; $D$. hendeli and $D$. decemseriata were collected more than 85 years ago, by the Austrian entomologist Hans Zerny in 1927, during an expedition to Fazenda Taperinha, in Santarém (Zerny 1929). At that time, the specimens were deposited at the Naturhistorisches Museum Wien (NMW). There, in 1936, the entomologist Friedrich Hendel determined 11 specimens as D. annularis Sturtevant, 1916 and nine as D. decemseriata (Hendel 1936). In 1990 Vilela and Bächli described $D$. hendeli, based on one of the specimens identified as D. annularis by Hendel (Vilela \& Bächili 1990). D. decemseriata which was described in 1936 by Hendel has not been found anywhere else. The type of M. brunnescens was collected by the geneticist Theodosius Dobzhansky in Belém-PA, in 1952 (Wheeler \& Takada 1963), and was apparently never collected again. D. caxiuana and D. speciosa, in contrast, have been recorded more recently. In 2001, D. speciosa was recorded from cacauí flowers (Thebroma speciosum Willd. Ex Spreng) (Silva \& Martins 2004 ) and was thus collected from flowers in various municipalities across the state, as observed in the MPEG (Table 1). D. caxiuana was collected in 2008 in banana traps (Gottschalk et al. 2012). It is possible that these taxa are locally endemic to the Amazon Biome, however, it is possible that their rarity is due to collecting limitations.

There is still a lot to be learnt about the richness and composition of Drosophilidae species in the Amazon biome. Despite being the second largest state of Brazil, and being within the Amazon biome, Pará comes third in Drosophilidae species richness in the country, with $17 \%$ of locally native species, behind the states of São Paulo and Santa Catarina (Gottschalk et al. 2008). Considering the geographic coverage of the records in the collections and literature records, it is obvious that there is still much to be learned about the region's biodiversity. The known distribution of poorly sampled, diverse groups such as the Drosophilidae often reflects where past collecting efforts were more concentrated, rather than the real local diversity. Only $24 \%$ of the species known to occur in the state were not represented in the collections studied and those, in turn, have contributed to widen the known geographic distribution of $21 \%$ of the species in the list. This result highlights the importance of scientific collections as a source of information on local biodiversity. Most records, either in the literature or in the collections, are from material collected with banana baits. It is possible that the list presented here can be enriched not only by collecting in places that have not been sampled, but also by using other sources, such as flowers, fungi, decomposing leaves and other attractants.

\section{Acknowledgements}

We thank the MPEG technicians José A. Pena and Luís Augusto Quaresma, for information on the localities described on the labels of specimens, coordination and making available equipment necessary to conduct this work; Leonardo C. Trevelin plotted the maps; Ana Luiza C. Brasil and Angélico A. Flores provided references; and Marcos S. Fialho made corrections to the manuscript. We thank Bridget Johnson for providing a review of the English in this manuscript. The Conselho Nacional de Desenvolvimento Científico e Tecnológico (CNPq) provided a scholarship (process number 380618/2010-9). We also thank Instituto Nacional de Ciência e Tecnologia (INCT) and Programa de Pesquisa em Biodiversidade Amazônia Oriental (PPBio).

\section{Conflicts of interest}

The authors declare that they have no conflict of interest related to the publication of this manuscript.

\section{References}

ACURIO, A., RAFAEL, V., CESPEDES, D. \& RUIZ, A. 2013. Description of a New Spotted-Thorax Drosophila: Drosophilidae) Species and its Evolutionary Relationships Inferred by a Cladistic Analysis of Morphological traits. Ann. Entomol. Soc. Am. 106(6):695-705.

BÄCHLI, G., VILELA, C.R., ESCHER, S.A. \& SAURA, A. 2004. The Drosophilidae (Diptera) of Fennoscandia and Denmark. Fauna Entomol. Scand. 39: 362 p. 
BÄCHLI, G. 2015. TAXODROS: The database on taxonomy of Drosophilidae. Eletronic Database accessible at http://www.taxodros.uzh.ch/. (last access in 19 November 2015).

BICUDO, H.E.M.C. 1973. Reproductive isolation in the saltans group of Drosophila. I. The saltans subgroup. Genética, 44:313-329.

BURLA, H., CUNHA, A.B. DA, CORDEIRO, A.R., DOBZHANSKY, T., MALOGOLOWKIN, C. \& PAVAN, C. 1949. The willistoni group of sibling species of Drosophila. Evolution. 3:300-314.

BURLA, H. \& PAVAN, C. 1953. The calloptera group of species (Drosophila, Diptera). Rev. Brasil. Biol. 13(4):291-314.

BURLA, H. 1956. Die Drosophilidengattung Zygothrica und ihre beziehung zur Drosophilauntergattung Hirtodrosophila. Mitt. Zool. Mus. Berl. 32:189-321.

CULIK, M.P. \& VENTURA, J.A. 2009. New species of Rhinoleucophenga, a potencial predator of pineapple mealybugs. Pesq. Agropec. Bras. 44(4):417-420.

DAVID, J.R., ARARIPE, L.O., BITNER-MATHÉ, B.C., CAPY, P., GOÑI, B., KLACZKO, L.B., LEGOUT, H., MARTINS, M., VOUIDIBIO, J., YASSIN, A. \& MORETEAU, B. 2006. Quantitative trait analysis and geographic variability of natural populations of Zaprionus indianus, a recent invader in Brazil. Heredity. 96:53-62.

DE TONI, D.C., BRISSON, J.A. HOFMANN, P.R.P. MARTINS, M. \& HOLLOCHER, H. 2005. First record of Drosophila parthenogenetica and D. neomorpha, cardini group, Heed, 1962 (Drosophila, Drosophilidae), in Brazil. DIS. 88: 33-38. http://www.ou.edu/journals/dis/DIS88/Research/R2.pdf\#DeToni

DOBZHANSKY, T. \& PAVAN, C. 1943. Studies on Brazilian species of Drosophila. Bol. Facul. Fil. Ciên. E Letr. 36:7-72.

DOBZHANSKY, T. 1944. Experiments on sexual isolation in Drosophila. III. Geographic strains of Drosophila sturtevanti. Proc. Natl. Acad. Sci. 30(11):335-339.

DOBZHANSKY, T. \& MAYR, E. 1944. Experiments on sexual isolation in Drosophila. Proc. Natl. Acad. Sci. 30:238-244.

DOBZHANSKY, T. \& SREISINGER, G. 1944. Experiments on sexual isolation in Drosophila. II. Geographic strains of Drosophila prosaltans. Genetics. 30:340-345.

DOBZHANSKY, T. \& PAVAN, C. 1950. Local and seasonal variations in relative frequencies of species of Drosophila in Brazil. J. Anim. Ecol. 19:1-14. http:// www.dgrc.kit.ac.jp/ jdd/class/070101/07010154.pdf

DOBZHANSKY, T. \& CUNHA, A.B. 1955. Differentiation of nutritional preferences in Brazilian species of Drosophila. Ecology. 36:34-39.

DUDA, O. 1927. Die sudamerikanischen Drosophiliden (Dipteren) unter Beruckssichtigung auch der anderen neotropischen sowie der nearktischen Arten. Archiv. Naturgesch. 91:1-228.

FIGUERO, M. \& RAFAEL, V. 2011. Dos nuevas especies del grupo Drosophila onychophora (Diptera, Drosophilidae) em los bosques de Polylepis de Palallacta, Pichincha, Ecuador. Iheringia 101(4):342-349.

FIGUERO, M.L., LEÓN, R., RAFAEL, V. \& CÉSPEDES, D. (2012). Cuatro nuevas espécies del grupo Drosophila onychophora (Diptera, Drosophilidae) em el Parque Arqueológico Rumipamba, Pichincha, Ecuador. Iheringia. 102(2):212-220.

GOTTSCHALK, M.S., HOFMANN, P.R.P. \& VALENTE, V.L.S. 2008. Diptera, Drosophilidae: historical occurrence in Brazil. Check List. 4(4):485-518.

GOTTSCHALK, M.S., MARTINS, M.B., PRAXEDES, C.L.B. \& MEDEIROS, H.F. 2012. A new Amazonian species from the Drosophila annulimana species group (Diptera, Drosophilidae). Rev. Bras. Entomol. 56(4):431-435. http:// www.scielo.br/pdf/rbent/v56n4/v56n4a06.pdf

GRIMALDI, D.A. 1987. Phylogenetics and taxonomy of Zygothrica (Diptera: Drosophilidae). Bull. Am. Mus. Nat. Hist. 186:103-268.

GRIMALDI, D.A. 1990. Revision of Zygothrica (Diptera: Drosophilidae), Part II. The first African species, two new Indo-Pacific groups, and the bilineata and samoaensis species groups. Am. mus. novit. 2964:1-31.

GUILLÍN, E.R. \& RAFAEL, V. 2015. Three new species of Drosophila tripunctata group (Diptera: Drosophilidae) in the eastern Andes o Ecuador. Rev. peru. Boil. 22(3):289-296.

HEED, W.B. \& RUSSELL, J.S. 1971. Phylogeny and population structure in island and continental species of the cardini group of Drosophila studied by inversion analysis. Tex. Univ. Publ. 7103: 91-130.
HENDEL, F. 1936. Ergebnisse einer zoologischen Sammelreise nach Brazilien insbesondere in das Amazonasgebiet, ausgefuhrt von Dr. H. Zerny. X. Teil. Diptera. Muscidae acalyptratae (excl. Chloropidae). Ann. des K.K. Naturhist. Hofmus. 47:61-106.

HORTAL, J., BELLO, F., DINIZ-FILHO, J.A.F, LEWINSOHN, T.M., LOBO, J.M. \& LADLE, R.J. 2015. Seven shortfalls that beset large-scale knowledge of biodiversity. Ann. Ver. Ecol. Syst. 46:523-49.

IBGE 2010. IBGE Instituto Brasileiro de Geografia e Estatística. Eletronic Database accessible at http://www.ibge.gov.br/estadosat/perfil.php?sigla=pa. (last access in 08 December 2015).

JUNGES, J. \& GOTTSCHALK, M.S. 2014. Two New Species of the New World Genus Rhinoleucophenga (Diptera: Drosophilidae). J. Insect Sci. 14(157):1-5.

JUNGES, J., GOTTSCHALK, M.S., LORETO, E.L.S. \& ROBE, L.J. 2016. Two new species of Mycodrosphila (diptera: Drosophilidae) proposed by molecular and morphological approaches, with a key to American species. Rev. Bras. Ent. 60:30-39.

MAGALHÃES, L.E. 1956. Description of four new species of the saltans group of Drosophila (Diptera). Rev. Bras. Biol. 16:273-280.

MAGALHÃES L.E. 2010. Reminiscências do tempo de drosófilas. Pesq. Fapesp, Vol. 168, p.78-79.

MARTINS, M.B. 2001. Guilds of Drosophilids on forest fragments. In Lessons from Amazônia. The Ecology and Conservation of a fragmented forest. (R.O BIERREGAARD, C. Gascon, T.E. LOVEJOY \& R. MESQUITA, Orgs). University Yale. Yale, 175-186.

MARTINS, M.B. \& OLIVEIRA, L. 2007. Dinâmica espacial de Drosophila em remanescente de mata na Reserva do Mocambo e suas áreas adjacentes. In Mocambo: Diversidade e Dinâmica Biológica da Área de Pesquisa Ecológica do Guamá (APEG). (J.I. GOMES, M.B. MARTINS, R.C.V. MARTINS-DASILVA \& S.S. ALMEIDA, Orgs.). Museu Paraense Emílio Goeldi: Centro de Pesquisa Agroflorestal da Amazônia Oriental, Belém, Pará, p. 389-404.

MARTINS, M.B. \& SANTOS, R.C.O. 2007. Sítios de criação de Drosophila na Reserva Mocambo, Belém, Pará. In Mocambo: Diversidade e Dinâmica Biológica da Área de Pesquisa Ecológica do Guamá (APEG). (J.I. GOMES, M.B. MARTINS, R.C.V. MARTINS-DA-SILVA \& S.S. ALMEIDA, Orgs.). Museu Paraense Emílio Goeldi: Centro de Pesquisa Agroflorestal da Amazônia Oriental, Belém, Pará, p. 315-329.

MARTINS, M.B., FURTADO, I.S., COSTA, J.C.E., PENA, J.A.N., COSTA, L.S RENDEIRO, A.C. 2008. Lista de espécies de Drosophilidae da área do Urucu. In Biodiversidade da província petrolífera de Urucu. (A.L. PRUDENTE, D. ROSÁRIO, L. MONTAG, M. MONNERAT, M. MARTINS, P.R. CABRAL \& S. LIMA. (Orgs). 1 ed. Manaus: IPSIS, v.1, p. 120-221.

MORAES, B.C., COSTA, J.MN., COSTA, A.C.L. \& COSTA, M.H. 2005. Variação espacial e temporal da precipitação no estado Pará. Acta Amazon. 35(2):207-214.

PATTERSON, J.T. \& STONE, W.S. 1952. Evolution in the genus Drosophila. New York. Macmillan Co. $610 \mathrm{p}$

PAVAN, C. 1950. Espécies Brasileiras de Drosophila. II. Bol. Facul. Fil. Ciên. e Letr. 111(8):1-38.

PAVAN, C. 1959. Relações entre populações naturais de Drosophila e o meio ambiente. Facul. Fil. Ciên. e Letr. 11:1-81.

PAVAN, C. \& CUNHA, A.B. 1947. Espécies Brasileira de Drosophila. Bol. Facul. Fil. Ciên. E Letr. $N^{\circ} 86-$ Biologia Geral $N^{\circ} 7$.

POPPE, J.L., SCHMITZ, H.J., GRIMALDI, D. \& VALENTE, V.L.S. 2014. High diversity of Drosophilidae (Insecta, Diptera), in the Pampas Biome of South America, with descriptionsof new Rhinoleucophenga species. Zootaxa 3779(2):215-2145.

PRAXEDES, C.L.B. \& MARTINS, M.B. 2014. Inventário biológico: riqueza biodiversidade local e regional de Drosophilidae (Diptera) frugívoros. In Caxiuanã: Desafios para Conservação de uma Floresta Nacional na Amazônia, P. Lisboa, Org.). $4^{\circ}$ ed. Museu Paraense Emílio Goeldi, Belém, Pará, p. 521-537.

RAFAEL, V. \& VELA, D. 2003. Drosophila yangana sp. Nov. um nuevo miembro del grupo repleta, subgrupo inca (Diptera: Drosophilidae). Rev. Pontif. Univ. Catol. Del Ecua. 71:129-139.

RATCOV, V. \& VILELA, C.R. 2007. A new Neotropical species of spot-thoraxed Drosophila (Diptera, Drosophilidae). Rev. Bras. Entomol. 51(3):305-311. http://www.scielo.br/pdf/rbent/v51n3/v51n3a09.pdf. 
ROBE, L.J.R., MACHADO, S., BOLZAN, A.R., SANTOS, J.P.dos, VALER, F.B., SANTOS, A.P., BLAUTH, M.L. \& GOTTSCHALK, M.S. 2014. Comparative ecological niche modeling and evolutionary ecology of Neotropical mycophagous Drosophilidae (Diptera) species. Stud. Neotrop. Fauna Environ. 2014.925370.

SANTOS, R.C.O. \& MARTINS, M.B. 2000. A new record and breeding host plant for a species of the D. flavopilosa group (Drosophilidae, Drosophila). In International Congress of Entomology. Foz do Iguaçu, PR, Brazil. Annals of the XXI International Congress of Entomology. p. 453.

SCHMITZ, H.J., GOTTSCHALK, M.S. \& VALENTE, V.L.S. 2009. Rhinoleucophenga joaquina sp. nov. (Diptera: Drosophilidae) from the Neotropical Region. Neotrop. Entomol. 38(6): 786-790. http://www.scielo.br/pdf/ne/v38n6/12.pdf

SCHMITZ, H.J., AMADOR, R.B., FERREIRA, J.E.D., MAUÉS, M.M., NASCIMENTO, I.M. \& MARTINS, M.B. 2013. Relações biodiversidade $v s$. clima em escala local: Um estudo de caso em busca de padrões espaço-temporais em insetos. In Cenários para a Amazônia: Clima Biodiversidade e uso da Terra, T. Emilio; F. Luizão, Org. $1^{\circ}$ ed. Instituto de Pesquisa da Amazônia, Manaus, Amazonas, p. 204-206.

SILVA, A.A.R. \& MARTINS, M.B. 2004. A new anthophilic species of Drosophila Fallén belonging to the bromeliae group of species (Diptera, Drosophilidae). Rev. Bras. Zool. 21(3): 435-437. http://www.scielo.br/pdf/rbzool/v21n3/21890.pdf

SILVA, A.A.R. \& MARTINS, M.B. 2009. Polinização de cacauí Theobroma speciosum Willd. ex Spreng (Sterculiaceae) por drosofilídeos em área de ocorrência natural. In Caxiuanã: Desafios para Conservação de uma Floresta Nacional na Amazônia, P. Lisboa, Org.). $3^{\circ}$ ed. Museu Paraense Emílio Goeldi, Belém, Pará, p. 431-440.

STREISINGER, G. 1946. The cardini species group of the genus Drosophila. Jour. New York ent. Soc. 54:105-113.

TIDON, R., GOTTSCHALK, S.M., MARTINS, M.B. \& SCHIMTZ, H.J. 2015. CTFB: Catálogo Taxonômico da Fauna do Brasil. Eletronic Database accessible at http://fauna.jbrj.gov.br/fauna/listaBrasil/ConsultaPublicaUC/ConsultaPublicaUC. do. (last access in 3 December 2015).

TOSI, D., MARTINS, M., VILELA, C.R. \& PEREIRA, M.A.Q.R. 1990. On a new cave-dwelling species of bat-guano-breeding Drosophila closely related to D. repleta Wollaston (Diptera, Drosophilidae). Rev. Bras. Genet. 13:19-31.

TOWNSEND, J.I. 1954. Cryptic subspeciation in Drosophila belonging to the subgenus Sophphora. Am. Nat. 88 (842):339-351.
VAL, F.C. 1982. The male genitalia of some Neotropical Drosophila: Notes and illustrations. Pap. Avulsos Zool. 34:309-347.

VIDAL, M.C. \& VILELA, C.R. 2015. A New Species of Rhinoleucophenga (Diptera: Drosophilidae) From the Brazilian Cerrado Biome Associated with Extrafloral Nectaries of Qualea grandiflora (Vochysiaceae). Ann. Entomol. Soc. Am. 108(5):932-940.

VILELA, C.R. 1983. A revision of the Drosophila repleta species group) Diptera, Drosophilidae). Rev. Bras. Ent. 27(1):1-114.

VILELA, C.R. \& BÄCHLI, G. 1990. Taxonomic studies on Neotropical species of seven genera of Drosophilidae (Diptera). Mitt. Schweiz. Entomol. Ges. 63:1-332.

VILELA, C.R. \& BÄCHLI, G. 2004. On the identities of nine Neotropical species of Hirtodrosophila (Diptera, Drosophilidae). Mitt. Schweiz. Entomol. Ges. 77:161-195.

VILELA, C.R. \& BÄCHLI, G. 2005. Three new species of Neotropical Drosophilidae (Diptera). Mitt. Schweiz. Entomol. Ges. 78:143-165.

VILELA, C.R \& BÄCHLI, G. 2007. Revision of the Neotropical genus Paraliodrosophila (Diptera, Drosophilidae). Mitt. Schweiz. Entomol. Ges. 80:291-317.

WASSERMAN, M. 1962. Cytological studies of the repleta group of the genus Drosophila. VI. The fasciola subgroup. Univ. Texas Publi. 6205:119-134.

WHEELER, M.R. 1954. Taxonomic studies on American Drosophilidae. Univ. Texas Publi. 5422:47-64.

WHEELER, M.R. 1959. A Nomenclatural Study of the Genus Drosophila. Univ. Texas Publi. 5914:181-205.

WHEELER, M.R. \& TAKADA, H. 1963. A revision of the American species of Mycodrosophila (Diptera, Drosophilidae). Ann. Entomol. Soc. Am. 56:392-399.

ZERNY, H. 1929. Ergebnisse einer zoologischen Sammelreise nach Brasilien, insbesondere in das Amazonasgebiet, ausgefürt von Dr. H. Zerny.Vorbemerkung. Ann. Naturhist. Mus. Wien. 43:243-255.

Received: 05/03/2016

Revised: 07/11/2016

Accepted: 28/02/2017

Published online: $27 / 03 / 2017$ 